\title{
UAV-g 2019: Unmanned Aerial Vehicles in Geomatics
}

\author{
Francesco Nex@ \\ Faculty of Geo-Information Science and Earth Observation (ITC), University of Twente, \\ Enschede 7500 AE, The Netherlands; f.nex@utwente.nl; Tel.: +31-534896639
}

Received: 9 September 2019; Accepted: 9 September 2019; Published: 19 September 2019

check for updates

\begin{abstract}
Unmanned aerial vehicle in geomatics (UAV-g) is a well-established scientific event dedicated to UAVs in geomatics and remote sensing. In the different editions of the journal, new scientific challenges have increased their synergy with adjacent domains, such as robotics and computer vision, thereby increasing the impact of this conference. The 2019 edition has been hosted by the University of Twente (The Netherlands) and has attracted about 300 participants for the full three-day program. Researchers from 36 different countries (from all continents) have presented 89 accepted papers in 17 oral and 2 poster sessions. The presented papers covered multi-disciplinary topics, such as photogrammetry, natural resources monitoring, autonomous navigation, and deep learning. All these contributions have in common the use of UAV platforms for the innovative acquisition and processing of the acquired data and information extracted from the surrounding environment.
\end{abstract}

Keywords: UAV; drones; photogrammetry; remote sensing; robotics; computer vision

\section{The 2019 Edition}

Unmanned aerial vehicles (UAVs or 'drones') have become popular instruments for a wide range of emerging applications, such as mapping, search and rescue, infrastructure monitoring, precision farming, the transport of goods, and film-making. The UAV market has been valued at more than 100 US\$ billion and the outlook is extremely promising for subsequent years. The economic boom has boosted the scientific and technological development of UAV technologies in the last decade, as demonstrated by the growing number of scientific works dealing with this technology.

In this context, UAV-g was initiated in 2011 in Zurich as the ISPRS (International Society of Photogrammetry and Remote Sensing) scientific event dedicated to UAVs in geomatics and remote sensing. Three other editions took place in Rostock (2013), Toronto (2015), and Bonn (2017), making UAV-g a well-established and recognized event, even outside the ISPRS community. In the various editions, new scientific challenges and technological developments have made explicit the need for an inter-disciplinary approach, leading to stronger synergies with adjacent disciplines, such as robotics and computer vision.

UAV-g 2019 took place on 10-12 June 2019. For the first time in its history, UAV-g was hosted during the ISPRS Geospatial Week (GSW, www.gsw2019.org), reaching a larger audience involved in various remote sensing disciplines. Its setting at the University of Twente (Enschede, The Netherlands) campus (along with its facilities) enabled demonstrations and exhibitions related to recent developments in unmanned platform technologies.

UAV-g 2019 brought together experts from different domains. Besides experts in remote sensing and geoscience, researchers from robotics, computer vision, and artificial intelligence joined this event. This multidisciplinary environment was also reflected in the scientific committee, composed of 33 experts with very different areas of expertise and working in 16 countries all over the world.

The paper submission was successful: 120 papers were initially submitted, and 89 of them were accepted after the scientific committee revision process; 15 ISPRS Annals and 74 Archives papers were 
published on the ISPRS website. The received papers reflect the multidisciplinary nature of the event, ranging from the study of the natural environment to on-board sensor development and autonomous navigation. The keywords of the published papers are summarized in Figure 1. These contributions have also confirmed the relevance of UAV technology worldwide: 36 different countries from five continents were represented in the list of the papers' authors (Figure 2).

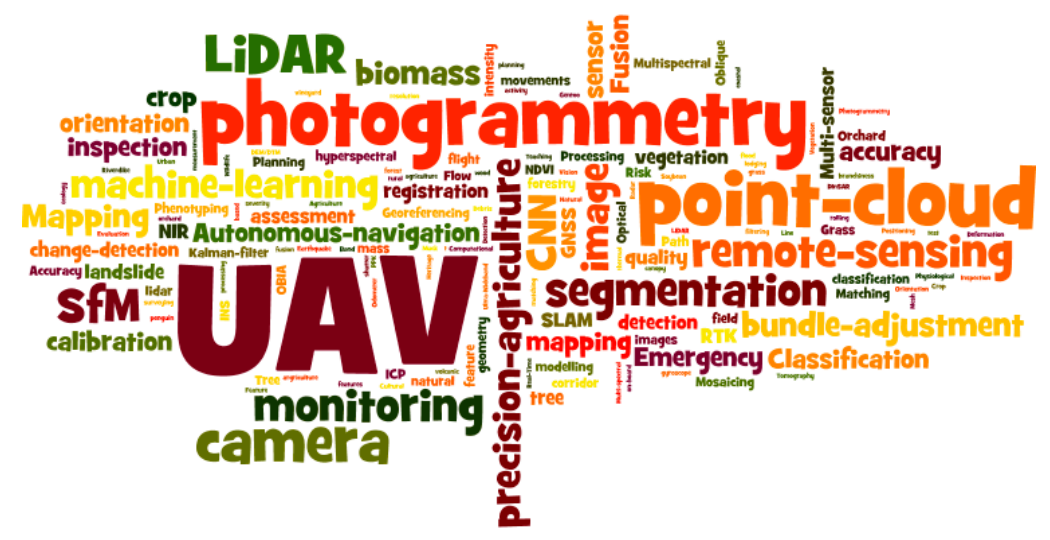

Figure 1. Sketch of the keywords used in the accepted papers (Wordle visualization).

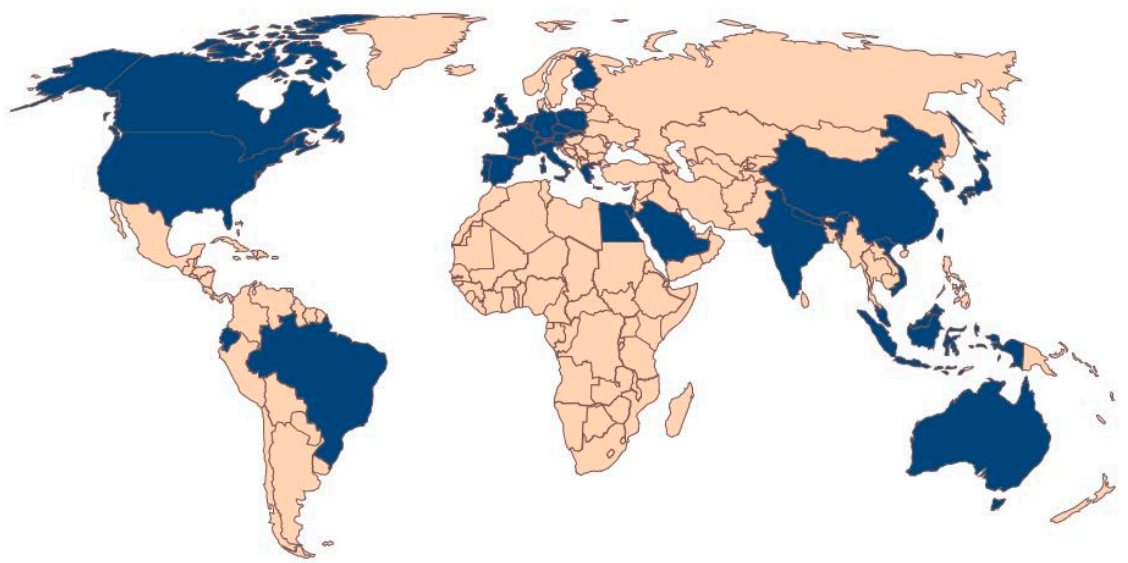

Figure 2. Countries represented in the affiliations of the accepted papers (in blue).

A total of 17 oral sessions (four plenary and the others in parallel) were organized in the three full day program. Two poster sessions and a session dedicated to European H2020 projects dealing with the developments of UAV studies were also organized. An overview of these sessions is provided in Section 2.

Three invited speakers presented the newest developments and trends in different aspects of the UAV domain. Edward Anderson (https://www.gsw2019.org/speaker/edward-anderson-worldbank/) (opening keynote of the ISPRS Geospatial week) gave a presentation on the use of new technologies (such as UAVs and artificial intelligence) for urban resilience in Africa. Pablo Zarco-Tejada (https://www.gsw2019.org/speaker/pablo-zarco-tejada-the-university-of-melbourne/) presented on the recent trends in the use of UAVs for precision agriculture and forestry monitoring. Margarita Chli (https://www.gsw2019.org/speaker/margarita_chli/) (joint keynote with parallel other conferences) showed how vision-based perception is boosting the intelligence of flying robots.

The presence of 20 sponsors at the ISPRS GeoSpatial Week (https://www.gsw2019.org/sponsors-2/), many of them operating in the UAV domain, further confirmed that UAV-g is a relevant event to create synergy, learn about recent developments, and exchange views on the future directions of UAV research, applications, and services. In this regard, the Drones MDPI journal sponsored the UAV-g Best Paper Award. 
The advertisements through the conference website (www.uav-g.com) and the Twitter and Facebook account increased the interest for the ISPRS Geospatial Week that had about 750 registrations, while UAV-g received about 300 participants.

\section{Oral Sessions}

The oral sessions were organized according to different areas that can be summarized as three main topics: (i) photogrammetry and geomatics developments, (ii) natural resources and environmental applications, and (iii) synergies with robotics and computer vision. In the following sections, a detailed explanation of the sessions hosted in each of these thematic areas will be given.

\subsection{Geomatics Developments in $U A V$}

Under this topic area, six sessions were organized on the use of UAV in photogrammetry and geomatics applications, in line with the long tradition of the UAV-g conference. In the two sessions on UAV photogrammetry, the contributions investigated the accuracy of image orientation [1] and the geometric quality of the generated point clouds [2-5], showing how the accuracy of photogrammetric products can be influenced by different image configurations, sensors, and software. The investigation of new devices, such as RTK receivers on low cost drones, were then discussed in other contributions [6-9], highlighting the remaining problems of these techniques and suggesting the best practices to be followed. The integration of different sensors on-board a UAV [10] and the adoption of new sensors, such as spherical cameras [11], showed the larger flexibility of the newest platforms to host several sensors with (often) relevant sizes. Other contributions showed how UAV data can be integrated together $[10,12]$ or embedded in multi-source systems $[13,14]$ to build larger and more complex solutions. This edition of UAV-g was also characterized by the increased number of contributions dealing with the use of LiDAR [15-18] and SAR [19] sensors. Lastly, relevant contributions were presented on the inclusion of UAVs in university education and policy [20,21].

\subsection{Natural Resources and Environmental Uses of UAVs}

The increased interest in the use of UAVs for environmental monitoring has been confirmed by the larger number of contributions dealing with precision farming and environmental monitoring. This led to two sessions on precision farming, two sessions on agriculture and forest monitoring, one session on environmental monitoring, and another on emergency and natural hazards. In the precision farming sessions, studies on the detection of different crop species [22-24], prediction of biomass [25], or other relevant characteristics, such as phenotype [26], structure [27], and dimensions [28,29], were presented. The agriculture and forest monitoring sessions gave the opportunity to understand the most recent developments in tree species classifications [30,31] and in the estimation of parameters like crop height [32-34] and other morphometric properties [35]. The session on environmental monitoring showed how UAVs are, today, commonly adopted for monitoring applications, such as the detection of water bodies [36], glaciers [37], animals [38,39], and temperature profiles [40]. UAVs are also becoming a valuable instrument for emergency management, as shown. Examples on the use of UAVs for monitoring and mapping natural hazards like landslides [41], earthquakes [42-44], and flooding [45] were presented.

\subsection{Synergies with Robotics and Computer Vision in the Use of UAVs}

Studies in robotics, computer vision, and geomatics often have parallel paths and have led to synergy and collaboration in the last few years. Deep learning algorithms initially developed in computer vision are also becoming the standard in remote sensing. The development of autonomous navigation is gaining attention not only in robotics but also in mapping applications. The use of innovative sensors for data acquisition and processing, as well as their integration in more flexible solutions, have attracted the attention of all these communities in recent years. One session on UAV flight planning and navigation, one session on autonomous navigation, and two sessions on scene understanding using 
UAV data were organized during the conference. Different flight planning approaches were proposed to face critical acquisitions [46-48] and produce more reliable products [49,50]. Recent improvements on simultaneous localization and mapping (SLAM) algorithms [51,52], as well as the new integration of different sensors for autonomous navigation in indoor environments [53-55], were shown in a dedicated session. The recent developments in deep learning applied to UAV data and remote sensing applications were presented. These developments showed the potential of these algorithms in different applications, such as tree classifications [56-58], map generation [59], localizations [60], and real-time monitoring [61,62].

\section{Poster Sessions}

Two poster sessions were hosted on two different days of the conference. Well organized and self-explicative posters were produced by authors presenting works on different topics [63-89]. The poster sessions presented an important opportunity to debate conference topics and networking with researchers and experts in the UAV domain.

\section{Best Paper Award 2019}

Two awards were assigned for the best paper and the best poster, respectively. The best paper award (offered by Drones, MDPI) was assigned to [30] according to the scores received by the scientific committee during the revision process. The best poster award (offered by Whittles publisher) was assigned to [69] after the assessment of a panel composed of selected members of the scientific committee.

\section{Next Edition in 2021}

Almost two months before the conference, a call was opened to bid for the organization of the 2021 edition. The committee received four different applications from three different continents, confirming the great interest of the scientific community in this event. Each of these candidate hosting institutions was invited to present its proposal in front of the scientific committee and the ISPRS Council. The vote of this panel assigned the organization of UAV-g 2021 to the Inha University (Icheon, South Korea), with Prof. Taejung Kim acting as conference chair.

Funding: This research received no external funding.

Acknowledgments: The author would like to thank the organizing committee of the ISPRS Geospatial Week, the scientific committee (https://www.uav-g.com/scientific-committee/) of UAV-g 2019 for their excellent work in the review and scientific support during the event, as well as the sponsors that have contributed to the success of this event.

Conflicts of Interest: The author declares no conflict of interest.

\section{References}

1. Tekavec, J.; Oštir, K.; Lisec, A.; Štebe, G. A system for monitoring of UAV camera orientation: Design and initial analysis. ISPRS Ann. Photogramm. Remote Sens. Spat. Inf. Sci. 2019, IV-2/W5, 171-177. [CrossRef]

2. Przybilla, H.-J.; Gerke, M.; Dikhoff, I.; Ghassoun, Y. Investigations on the Geometric Quality of Cameras for UAV Applications Using the High Precision UAV Test Field Zollern Colliery. Int. Arch. Photogramm. Remote Sens. Spat. Inf. Sci. 2019, XLII-2/W13, 531-538. [CrossRef]

3. Przybilla, H.-J.; Lindstaedt, M.; Kersten, T. Investigations into the quality of image-based point clouds from UAV Imagery. Int. Arch. Photogramm. Remote Sens. Spat. Inf. Sci. 2019, XLII-2/W13, 539-545. [CrossRef]

4. Peterson, S.; Lopez, J.; Munjy, R. Comparison of UAV imagery-derived point cloud to terrestrial laser scanner point cloud. ISPRS Ann. Photogramm. Remote Sens. Spat. Inf. Sci. 2019, IV-2/W5, 149-155. [CrossRef]

5. Zhou, Y.; Rupnik, E.; Meynard, C.; Thom, C.; Pierrot-Deseilligny, M. Simulation and analysis of photogrammetric UAV image blocks: influence of camera calibration error. ISPRS Ann. Photogramm. Remote Sens. Spat. Inf. Sci. 2019, IV-2/W5, 195-200. [CrossRef]

6. Taddia, Y.; Stecchi, F.; Pellegrinelli, A. Using DJI Phantom 4 RTK drone for topographic mapping of coastal areas. Int. Arch. Photogramm. Remote Sens. Spat. Inf. Sci. 2019, XLII-2/W13, 625-630. [CrossRef] 
7. Peppa, M.V.; Hall, J.; Goodyear, J.; Mills, J.P. Photogrammetric assessment and comparison of DJI Phantom 4 pro and phantom 4 RTK small unmanned aircraft systems. Int. Arch. Photogramm. Remote Sens. Spat. Inf. Sci. 2019, XLII-2/W13, 503-509. [CrossRef]

8. Stöcker, C.; Nex, F.; Koeva, M.; Gerke, M. UAV-based cadastral mapping: An assessment of the impact of flight parameters and ground truth measurements on the absolute accuracy of derived orthoimages. Int. Arch. Photogramm. Remote Sens. Spat. Inf. Sci. 2019, XLII-2/W13, 613-617.

9. Tufarolo, E.; Vanneschi, C.; Casella, M.; Salvini, R. Evaluation of camera positions and ground points quality in a GNSS-NRTK based UAV survey: preliminary results from a practical test in morphological very complex areas. Int. Arch. Photogramm. Remote Sens. Spat. Inf. Sci. 2019, XLII-2/W13, 637-641. [CrossRef]

10. Bakuła, K.; Ostrowski, W.; Pilarska, M.; Szender, M.; Kurczyński, Z. Evaluation and calibration of fixed-wing multisensor UAV mobile mapping system: Improved results. Int. Arch. Photogramm. Remote Sens. Spat. Inf. Sci. 2019, XLII-2/W13, 189-195.

11. Calantropio, A.; Chiabrando, F.; Einaudi, D.; Teppati Losè, L. $360^{\circ}$ images for UAV multisensor data fusion: First tests and results. Int. Arch. Photogramm. Remote Sens. Spat. Inf. Sci. 2019, XLII-2/W13, 227-234. [CrossRef]

12. Gonçalves, J.A.; Jordão, N.; Pinhal, A. Orientation of UAV image blocks by surface matching. Int. Arch. Photogramm. Remote Sens. Spat. Inf. Sci. 2019, XLII-2/W13, 317-321.

13. Schmitz, S.; Weinmann, M.; Ruf, B. Automatic co-registration of aerial imagery and untextured model data utilizing average shading gradients. Int. Arch. Photogramm. Remote Sens. Spat. Inf. Sci. 2019, XLII-2/W13, 581-588. [CrossRef]

14. Alamouri, A.; Gerke, M.; Batzdorfer, S.; Becker, M.; Bestmann, U.; Bobbe, M.; Khedar, Y.; Blume, T.; Schattenberg, J.; Schmiemann, J. The joint research project ANKOMMEN - Exploration using automated UAV and UGV. Int. Arch. Photogramm. Remote Sens. Spat. Inf. Sci. 2019, XLII-2/W13, 165-172. [CrossRef]

15. Vepakomma, U.; Cormier, D. Valuing forest stand at a glance with UAV based Lidar. Int. Arch. Photogramm. Remote Sens. Spat. Inf. Sci. 2019, XLII-2/W13, 643-647. [CrossRef]

16. Davidson, L.; Mills, J.P.; Haynes, I.; Augarde, C.; Bryan, P.; Douglas, M. Airborne to UAS Lidar: An analysis of UAS Lidar ground control targets. Int. Arch. Photogramm. Remote Sens. Spat. Inf. Sci. 2019, XLII-2/W13, 255-262. [CrossRef]

17. Pu, S.; Xie, L.; Ji, M.; Zhao, Y.; Liu, W.; Wang, L.; Zhao, Y.; Yang, F.; Qiu, D. Real-time powerline corridor inspection by edge computing of UAV Lidar data. Int. Arch. Photogramm. Remote Sens. Spat. Inf. Sci. 2019, XLII-2/W13, 547-551. [CrossRef]

18. Shaw, L.; Helmholz, P.; Belton, D.; Addy, N. Comparison of UAV Lidar and imagery for beach monitoring. Int. Arch. Photogramm. Remote Sens. Spat. Inf. Sci. 2019, XLII-2/W13, 589-596. [CrossRef]

19. Deguchi, T.; Sugiyama, T.; Kishimoto, M. R\&D of drone-borne SAR system. Int. Arch. Photogramm. Remote Sens. Spat. Inf. Sci. 2019, XLII-2/W13, 263-267.

20. Freeman, P.K.; Freeland, R.S. Red tape in higher education institutions: UAV policy. ISPRS Ann. Photogramm. Remote Sens. Spat. Inf. Sci. 2019, IV-2/W5, 119-126. [CrossRef]

21. Reiss, M.L.L.; Mendes, T.S.G.; Andrade, M.R.M.; Amory, A.M.; de Lara, R.; Souza, S.F. RPAS in the support for photogrammetry education: Cases in topographic mapping and documentation of historical monuments. Int. Arch. Photogramm. Remote Sens. Spat. Inf. Sci. 2019, XLII-2/W13, 567-574. [CrossRef]

22. Grenzdörffer, G.J. Automatic generation of geometric parameters of individual cauliflower plants for rapid phenotyping using drone images. Int. Arch. Photogramm. Remote Sens. Spat. Inf. Sci. 2019, XLII-2/W13, 329-335.

23. Valente, J.; Doldersum, M.; Roers, C.; Kooistra, L. Detecting RUMEX OBTUSIFOLIUS weed plants in grasslands from UAV RGB imagery using deep learning. ISPRS Ann. Photogramm. Remote Sens. Spat. Inf. Sci. 2019, IV-2/W5, 179-185. [CrossRef]

24. Oliveira, R.A.; Näsi, R.; Niemeläinen, O.; Nyholm, L.; Alhonoja, K.; Kaivosoja, J.; Viljanen, N.; Hakala, T.; Nezami, S.; Markelin, L.; et al. Assessment of RGB and hyperspectral UAV remote sensing for grass quantity and quality estimation. Int. Arch. Photogramm. Remote Sens. Spat. Inf. Sci. 2019, XLII-2/W13, 489-494. [CrossRef] 
25. Johansen, K.; Morton, M.J.L.; Malbeteau, Y.; Aragon, B.; Al-Mashharawi, S.; Ziliani, M.; Angel, Y.; Fiene, G.; Negrao, S.; Mousa, M.A.A.; et al. Predicting biomass and yield at harvest of salt-stressed tomato plants using UAV imagery. Int. Arch. Photogramm. Remote Sens. Spat. Inf. Sci. 2019, XLII-2/W13, 407-411. [CrossRef]

26. Herrero-Huerta, M.; Rainey, K.M. High throughput phenotyping of physiological growth dynamics from UAS-based 3D modeling in soybean. Int. Arch. Photogramm. Remote Sens. Spat. Inf. Sci. 2019, XLII-2/W13, 357-361. [CrossRef]

27. Finn, A.; Melville-Smith, A.; Brinkworth, R. Extraction of vineyard macrostructure from sub-optimal sequences of aerial imagery. ISPRS Ann. Photogramm. Remote Sens. Spat. Inf. Sci. 2019, IV-2/W5, 103-110. [CrossRef]

28. Chauhan, S.; Darvishzadeh, R.; Lu, Y.; Stroppiana, D.; Boschetti, M.; Pepe, M.; Nelson, A. Wheat lodging assessment using multispectral UAV data. Int. Arch. Photogramm. Remote Sens. Spat. Inf. Sci. 2019, XLII-2/W13, 235-240. [CrossRef]

29. Miura, N.; Koyanagi, T.F.; Yokota, S.; Yamada, S. Can UAV Lidar derive vertical structure of herbaceous vegetation on riverdike? ISPRS Ann. Photogramm. Remote Sens. Spat. Inf. Sci. 2019, IV-2/W5, 127-132. [CrossRef]

30. Iseli, C.; Lucieer, A. Tree species classification based on 3D spectral point clouds and orthomosaics acquired by snapshot hyperspectral UAS sensor. Int. Arch. Photogramm. Remote Sens. Spat. Inf. Sci. 2019, XLII-2/W13, 379-384. [CrossRef]

31. Zaforemska, A.; Xiao, W.; Gaulton, R. Individual tree detection from UAV Lidar data in a mixed species woodland. Int. Arch. Photogramm. Remote Sens. Spat. Inf. Sci. 2019, XLII-2/W13, 657-663. [CrossRef]

32. Machado, M.V.; Tommaselli, A.M.G.; Tachibana, V.M.; Martins-Neto, R.P.; Campos, M.B. Evaluation of multiple linear regression model to obtain DBH of trees using data from a lightweight laser scanning system on-board a UAV. Int. Arch. Photogramm. Remote Sens. Spat. Inf. Sci. 2019, XLII-2/W13, 449-454. [CrossRef]

33. Becirevic, D.; Klingbeil, L.; Honecker, A.; Schumann, H.; Rascher, U.; Léon, J.; Kuhlmann, H. On the derivation of crop heights from multitemporal UAV based imagery. ISPRS Ann. Photogramm. Remote Sens. Spat. Inf. Sci. 2019, IV-2/W5, 95-102. [CrossRef]

34. Wilke, N.; Siegmann, B.; Frimpong, F.; Muller, O.; Klingbeil, L.; Rascher, U. Quantifying lodging percentage, lodging development and lodging severity using a UAV-based canopy height model. Int. Arch. Photogramm. Remote Sens. Spat. Inf. Sci. 2019, XLII-2/W13, 649-655. [CrossRef]

35. Finn, A.; Brinkworth, R.; Griffiths, D.; Peters, S. Determining morphometric properties of radiata pine using long wave infrared sensing and biologically-inspired vision. Int. Arch. Photogramm. Remote Sens. Spat. Inf. Sci. 2019, XLII-2/W13, 277-281. [CrossRef]

36. Belcore, E.; Piras, M.; Pezzoli, A.; Massazza, G.; Rosso, M. Raspberry PI 3 multispectral low-cost sensor for UAV based remote sensing. Case study in south-west Niger. Int. Arch. Photogramm. Remote Sens. Spat. Inf. Sci. 2019, XLII-2/W13, 207-214. [CrossRef]

37. Boesch, R.; Graf, C. Mass movements of an alpine rock glacier. Int. Arch. Photogramm. Remote Sens. Spat. Inf. Sci. 2019, XLII-2/W13, 215-219. [CrossRef]

38. Mustafa, O.; Braun, C.; Esefeld, J.; Knetsch, S.; Maercker, J.; Pfeifer, C.; Rümmler, M.-C. Detecting Antarctic seals and flying seabirds by UAV. ISPRS Ann. Photogramm. Remote Sens. Spat. Inf. Sci. 2019, IV-2/W5, 141-148. [CrossRef]

39. Firla, M.; Mustafa, O.; Pfeifer, C.; Senf, M.; Hese, S. Intraseasonal variability of guano stains in a remotely sensed penguin colony using UAV and satellite. ISPRS Ann. Photogramm. Remote Sens. Spat. Inf. Sci. 2019, IV-2/W5, 111-118. [CrossRef]

40. Finn, A.; Rogers, K.; Meade, J.; Skinner, J.; Zargarian, A. Preliminary evaluation of atmospheric temperature and wind profiles obtained using unmanned aerial vehicle based acoustic tomography. Int. Arch. Photogramm. Remote Sens. Spat. Inf. Sci. 2019, XLII-2/W13, 283-287. [CrossRef]

41. Rau, J.Y.; Jhan, J.P.; Andaru, R. Landslide deformation monitoring by three-camera imaging system. Int. Arch. Photogramm. Remote Sens. Spat. Inf. Sci. 2019, XLII-2/W13, 559-565. [CrossRef]

42. Alamouri, A.; Gerke, M. Development of a geodatabase for efficient remote sensing data management in emergency scenarioS. ISPRS Ann. Photogramm. Remote Sens. Spat. Inf. Sci. 2019, IV-2/W5, 87-93. [CrossRef]

43. Ghaffarian, S.; Kerle, N. Towards post-disaster debris identification for precise damage and recovery assessments from UAV and satellite images. Int. Arch. Photogramm. Remote Sens. Spat. Inf. Sci. 2019, XLII-2/W13, 297-302. [CrossRef] 
44. Chiabrando, F.; Giulio Tonolo, F.; Lingua, A. UAV direct georeferencing approach in an emergency mapping context. The 2016 Central Italy earthquake case study. Int. Arch. Photogramm. Remote Sens. Spat. Inf. Sci. 2019, XLII-2/W13, 247-253. [CrossRef]

45. Backes, D.; Schumann, G.; Teferele, F.N.; Boehm, J. Towards a high-resolution drone-based 3D mapping dataset to optimise flood hazard modelling. Int. Arch. Photogramm. Remote Sens. Spat. Inf. Sci. 2019, XLII-2/W13, 181-187. [CrossRef]

46. Palanirajan, H.K.; Alsadik, B.; Nex, F.; Oude Elberink, S. Efficient flight planning for building façade 3D reconstruction. Int. Arch. Photogramm. Remote Sens. Spat. Inf. Sci. 2019, XLII-2/W13, 495-502. [CrossRef]

47. Gagliolo, S.; Passoni, D.; Federici, B.; Ferrando, I.; Sguerso, D. U.PH.O AND MAGO: Two useful instruments in support of photogrammetric UAV survey. Int. Arch. Photogramm. Remote Sens. Spat. Inf. Sci. 2019, XLII-2/W13, 289-296. [CrossRef]

48. Radford, C.R.; Bevan, G. A calibration workflow for "prosumer" UAV cameras. Int. Arch. Photogramm. Remote Sens. Spat. Inf. Sci. 2019, XLII-2/W13, 553-558. [CrossRef]

49. Giudici, R.; Courtrai, L.; Lefevre, S. Mosaicing fidelity geometrical assessment based on surf point classification. Int. Arch. Photogramm. Remote Sens. Spat. Inf. Sci. 2019, XLII-2/W13, 309-315. [CrossRef]

50. Feng, C.; Yu, D.; Liang, Y.; Guo, D.; Wang, Q.; Cui, X. Assessment of influence of image processing on fully automatic UAV photogrammetry. Int. Arch. Photogramm. Remote Sens. Spat. Inf. Sci. 2019, XLII-2/W13, 269-275. [CrossRef]

51. Mohamed, H.A.; Moussa, A.; Elhabiby, M.M.; El-Sheimy, N. Improved reference key frame algorithm. ISPRS Ann. Photogramm. Remote Sens. Spat. Inf. Sci. 2019, IV-2/W5, 133-139. [CrossRef]

52. Sirmacek, B.; Rashad, R.; Radl, P. Autonomous UAV-based 3D-reconstruction of structures for aerial physical interaction. Int. Arch. Photogramm. Remote Sens. Spat. Inf. Sci. 2019, XLII-2/W13, 601-605. [CrossRef]

53. Cheng, D.-L.; Lai, W.-H. Application of self-organizing map on flight data analysis for quadcopter health diagnosis system. Int. Arch. Photogramm. Remote Sens. Spat. Inf. Sci. 2019, XLII-2/W13, 241-246. [CrossRef]

54. Zahran, S.; Masiero, A.; Mostafa, M.M.; Moussa, A.M.; Vettore, A.; El-Sheimy, N. UAVs enhanced navigation in outdoor GNSS denied environment using UWB and monocular camera systems. Int. Arch. Photogramm. Remote Sens. Spat. Inf. Sci. 2019, XLII-2/W13, 665-672. [CrossRef]

55. Zahran, S.; Moussa, A.; El-Sheimy, N. Enhanced UAV navigation using hall-magnetic and air-mass flow sensors in indoor environment. ISPRS Ann. Photogramm. Remote Sens. Spat. Inf. Sci. 2019, IV-2/W5, 187-194. [CrossRef]

56. Schenk, F.; Tscharf, A.; Mayer, G.; Fraundorfer, F. Automatic muck pile characterization from UAV images. ISPRS Ann. Photogramm. Remote Sens. Spat. Inf. Sci. 2019, IV-2/W5, 163-170. [CrossRef]

57. Natesan, S.; Armenakis, C.; Vepakomma, U. Resnet-based tree species classification using UAV images. Int. Arch. Photogramm. Remote Sens. Spat. Inf. Sci. 2019, XLII-2/W13, 475-481. [CrossRef]

58. Pessoa, G.G.; Santos, R.C.; Carrilho, A.C.; Galo, M.; Amorim, A. Urban scene classification using features extracted from photogrammetric point clouds acquired by UAV. Int. Arch. Photogramm. Remote Sens. Spat. Inf. Sci. 2019, XLII-2/W13, 511-518. [CrossRef]

59. Sahu, M.; Ohri, A. Vector map generation from aerial imagery using deep learning. ISPRS Ann. Photogramm. Remote Sens. Spat. Inf. Sci. 2019, IV-2/W5, 157-162. [CrossRef]

60. Schleiss, M. Translating aerial images into street-map-like representations for visual self-localization of UAVs. Int. Arch. Photogramm. Remote Sens. Spat. Inf. Sci. 2019, XLII-2/W13, 575-578. [CrossRef]

61. Jeon, I.; Ham, S.; Cheon, J.; Klimkowska, A.M.; Kim, H.; Choi, K.; Lee, I. A real-time drone mapping platform for marine surveillance. Int. Arch. Photogramm. Remote Sens. Spat. Inf. Sci. 2019, XLII-2/W13, 385-391. [CrossRef]

62. Brauneck, J.; Gattung, T.; Jüpner, R. Surface flow velocity measurements from UAV-based videos. Int. Arch. Photogramm. Remote Sens. Spat. Inf. Sci. 2019, XLII-2/W13, 221-226. [CrossRef]

63. Karantanellis, E.; Marinos, V.; Vassilakis, E. 3D hazard analysis and object-based characterization of landslide motion mechanism using UAV imagery. Int. Arch. Photogramm. Remote Sens. Spat. Inf. Sci. 2019, XLII-2/W13, 425-430. [CrossRef]

64. Tubau Comas, A.; Valente, J.; Kooistra, L. Automatic apple tree blossom estimation from UAV RGB imagery. Int. Arch. Photogramm. Remote Sens. Spat. Inf. Sci. 2019, XLII-2/W13, 631-635. [CrossRef] 
65. Okojie, J.A.; Effiom, A.E.; Tawiah, E.N.; Akpejiori, I.J. Computational time modelling for tree crown extraction from high resolution imagery using geographic object-based image analysis. Int. Arch. Photogramm. Remote Sens. Spat. Inf. Sci. 2019, XLII-2/W13, 483-488. [CrossRef]

66. Hassanein, M.; Khedr, M.; El-Sheimy, N. Crop row detection procedure using low-cost UAV imagery system. Int. Arch. Photogramm. Remote Sens. Spat. Inf. Sci. 2019, XLII-2/W13, 349-356. [CrossRef]

67. Shrestha, S.; Thapa, M.; Feng, L.G.Y.; Abdelkader, S.; Prinz, T.; Lehmann, J.; Fritze, H. Determination of surface velocity of a river using videos captured from unmanned aerial system (UAS). Int. Arch. Photogramm. Remote Sens. Spat. Inf. Sci. 2019, XLII-2/W13, 597-600. [CrossRef]

68. Stroppiana, D.; Pepe, M.; Boschetti, M.; Crema, A.; Candiani, G.; Giordan, D.; Baldo, M.; Allasia, P.; Monopoli, L. Estimating crop density from multi-spectral UAV imagery in maize crop. Int. Arch. Photogramm. Remote Sens. Spat. Inf. Sci. 2019, XLII-2/W13, 619-624. [CrossRef]

69. Andaru, R.; Rau, J.-Y. Lava dome changes detection at agung mountain during high level of volcanic activity using UAV photogrammetry. Int. Arch. Photogramm. Remote Sens. Spat. Inf. Sci. 2019, XLII-2/W13, 173-179. [CrossRef]

70. Morocho, V.; España, D.A.; Serrano, A.C.; Achig, R.; Crompvoets, J. Mass movements detection from UAV images analysis. Int. Arch. Photogramm. Remote Sens. Spat. Inf. Sci. 2019, XLII-2/W13, 461-467. [CrossRef]

71. Grznárová, A.; Mokroš, M.; Surový, P.; Slavík, M.; Pondelík, M.; Merganič, J. The crown diameter estimation from fixed wing type of UAV imagery. Int. Arch. Photogramm. Remote Sens. Spat. Inf. Sci. 2019, XLII-2/W13, 337-341.

72. Martínez-Sánchez, J.; González-de Santos, L.M.; Novo, A.; González-Jorge, H. UAV and satellite imagery applied to alien species mapping in NW Spain. Int. Arch. Photogramm. Remote Sens. Spat. Inf. Sci. 2019, XLII-2/W13, 455-459.

73. Lussem, U.; Bolten, A.; Menne, J.; Gnyp, M.L.; Bareth, G. Ultra-high spatial resolution UAV-based imagery to predict biomass in temperate grasslands. Int. Arch. Photogramm. Remote Sens. Spat. Inf. Sci. 2019, XLII-2/W13, 443-447. [CrossRef]

74. Imai, N.N.; Tommaselli, A.M.G.; Berveglieri, A.; Moriya, E.A.S. Shadow detection in hyperspectral images acquired by UAV. Int. Arch. Photogramm. Remote Sens. Spat. Inf. Sci. 2019, XLII-2/W13, 371-377. [CrossRef]

75. Hese, S.; Thiel, C.; Henkel, A. UAV based multi seasonal deciduous tree species analysis in The Hainich National Park using multi temporal and point cloud curvature features. Int. Arch. Photogramm. Remote Sens. Spat. Inf. Sci. 2019, XLII-2/W13, 363-370. [CrossRef]

76. Na, J.; Yang, X.; Fang, X.; Tang, G.; Pfeifer, N. Mapping artificial terraces from image matching point cloud in Loess Plateau of China. Int. Arch. Photogramm. Remote Sens. Spat. Inf. Sci. 2019, XLII-2/W13, 469-473. [CrossRef]

77. Jhan, J.P.; Rau, J.Y. A normalized surf for multispectral image matching and band co-registration. Int. Arch. Photogramm. Remote Sens. Spat. Inf. Sci. 2019, XLII-2/W13, 393-399. [CrossRef]

78. Giudici, R.; Courtrai, L.; Lefevre, S. An advanced benchmarking for image compositing evaluation. Int. Arch. Photogramm. Remote Sens. Spat. Inf. Sci. 2019, XLII-2/W13, 303-308. [CrossRef]

79. Son, J.; Lim, P.; Seo, J.; Kim, T. Analysis of bundle adjustments and epipolar model accuracy according to flight path characteristics of UAV. Int. Arch. Photogramm. Remote Sens. Spat. Inf. Sci. 2019, XLII-2/W13, 607-612. [CrossRef]

80. Lim, P.C.; Seo, J.; Son, J.; Kim, T. Analysis of orientation accuracy of an UAV image according to camera calibration. Int. Arch. Photogramm. Remote Sens. Spat. Inf. Sci. 2019, XLII-2/W13, 437-442. [CrossRef]

81. Kim, D.; Youn, J.; Kim, T.; Kim, G. Development of GPS satellite visibility simulation method under urban canyon environment. Int. Arch. Photogramm. Remote Sens. Spat. Inf. Sci. 2019, XLII-2/W13, 431-435. [CrossRef]

82. Balsi, M.; Prem, S.; Williame, K.; Teboul, D.; Délétraz, L.; Hebrard Capdeville, P.I. Establishing new foundations for the use of remotely-piloted aircraft systems for civilian applications. Int. Arch. Photogramm. Remote Sens. Spat. Inf. Sci. 2019, XLII-2/W13, 197-201. [CrossRef]

83. González-de Santos, L.M.; Martínez-Sánchez, J.; González-Jorge, H.; Novo, A.; Arias, P. First approach to UAV-based contact inspection: A smart payload for navigation in the neighbourhood of structures. Int. Arch. Photogramm. Remote Sens. Spat. Inf. Sci. 2019, XLII-2/W13, 323-328. 
84. Kang, J.; Lee, S.; Yeon, S.; Park, S. Improving 3d mesh quality using multi-directional UAV images. Int. Arch. Photogramm. Remote Sens. Spat. Inf. Sci. 2019, XLII-2/W13, 419-423. [CrossRef]

85. Bareth, G.; Lussem, U.; Menne, J.; Hollberg, J.; Schellberg, J. Potential of non-calibrated UAV-based RGB imagery for forage monitoring: Case study at the RENGEN long-term grassland experiment (RGE), Germany. Int. Arch. Photogramm. Remote Sens. Spat. Inf. Sci. 2019, XLII-2/W13, 203-206. [CrossRef]

86. Preethi Latha, T.; Naga Sundari, K.; Cherukuri, S.; Prasad, M.V.V.S.V. Remote sensing uav/drone technology as a tool for urban development measures in Apcrda. Int. Arch. Photogramm. Remote Sens. Spat. Inf. Sci. 2019, XLII-2/W13, 525-529. [CrossRef]

87. Kalantar, B.; Ueda, N.; Al-Najjar, H.A.H.; Moayedi, H.; Halin, A.A.; Mansor, S. UAV and lidar image registration: A SURF-based approach for ground control points selection. Int. Arch. Photogramm. Remote Sens. Spat. Inf. Sci. 2019, XLII-2/W13, 413-418. [CrossRef]

88. Jiang, S.; Jiang, W. UAV-based oblique photogrammetry for 3D reconstruction of transmission line: Practices and applications. Int. Arch. Photogramm. Remote Sens. Spat. Inf. Sci. 2019, XLII-2/W13, 401-406. [CrossRef]

89. Polewski, P.; Yao, W.; Fang, L. Vertical orientation correction of UAV image-based point clouds using statistical modeling of gable roof geometry. Int. Arch. Photogramm. Remote Sens. Spat. Inf. Sci. 2019, XLII-2/W13, 519-523. [CrossRef]

(C) 2019 by the author. Licensee MDPI, Basel, Switzerland. This article is an open access article distributed under the terms and conditions of the Creative Commons Attribution (CC BY) license (http://creativecommons.org/licenses/by/4.0/). 